\title{
ANALISIS SPASIAL TINGKAT KEKERINGAN SEBAGAI UPAYA MITIGASI KEGAGALAN PANEN DI KABUPATEN TAKALAR SULAWESI SELATAN
}

\author{
Nasiah Badwi, Rosmini Maru, dan Ibrahim Abbas \\ Fakultas Matematika dan Ilmu Pengetahuan Alam \\ J1. Daeng Tata Raya, Kampus Parangtambung, Makassar \\ Email : nasiahgeo@unm.ac.id
}

\begin{abstract}
This study aims to describe the characteristics of rainfall, evapotransirasi, spatial level drought mitigation efforts, and crop failures in Takalar Regency Research is done by the method of water balance (Water Balance) by Thornthwaite - Mather (1957), with a drought index criteria ILACO, B.V. (1981). The results showed the monthly rainfall in karakterisitk Regency Takalar ranged from $9.5 \mathrm{~mm}$ to $835.5 \mathrm{~mm}$. largest monthly rainfall stations Bonto Mangape and smallest Station South Palomo. Annual precipitation ranges from 2282, $8 \mathrm{~mm}$ up to $3546.69 \mathrm{~mm} / \mathrm{year}$. The characteristics of Evapotranspirasi potential monthly in Takalar Regency area ranges between $112.89 \mathrm{~mm}$ up to $170.76 \mathrm{~mm}$. Evapotranspirasi annual average potential of $1428.76 \mathrm{~mm}$ in the South to Palomo Station 1576.28 Station Patalassang in mm. High dryness and evenly throughout the Regency Takalar in July. The annual high level spatial drought spread across the eastern region to the South; Subdistricts of North Polongbangken, South Polongbangken and Mangngarabombang. Mitigation of crop failures by means of managing the plant in accordance with the availability of water. At the level of high keketingan planted plants Watermelons, cucumbers, and corn.
\end{abstract}

\begin{abstract}
Abstrak. Penelitian ini bertujuan untuk menggambarkan karakteristik curah hujan, evapotransirasi, agihan tingkat kekeringan, dan upaya mitigasi kegagalan panen di Kabupaten Takalar Penelitian ini dilakukan dengan metode neraca air (Water Balance) oleh Thornthwaite - Mather (1957), dengan kriteria indeks kekeringan ILACO, B.V. (1981). Hasil penelitian menunjukkan karakterisitk curah hujan bulanan di wilayah Kabupaten Takalar berkisar antara 9,5 mm hingga 835,5 mm. Curah hujan bulanan terbesar di stasiun Bonto Mangape dan terkecil di stasiun Palomo Selatan. Curah hujan tahunan berkisar antara 2282, $8 \mathrm{~mm}$ hingga 3546,69 mm/tahun. Karakteristik Evapotranspirasi potensial bulanan di wilayah Kabupaten Takalar berkisar antara 112,89 $\mathrm{mm}$ hingga 170,76 $\mathrm{mm}$. Evapotranspirasi potensial rerata tahunan sebesar 1428,76 mm di Stasiun Palomo Selatan hingga 1576,28 mm di Stasiun Patalassang. Tingkat kekeringan tinggi dan merata di seluruh wilayah Kabupaten Takalar yaitu pada bulan Juli. Agihan tingkat kekeringan tahunan tinggi tersebar di wilayah timur ke selatan yaitu; Kecamatan Polongbangken Utara, Polongbangken Selatan dan Mangngarabombang. Mitigasi kegagalan panen dengan cara mengelola tanaman sesuai dengan ketersediaan air. Pada tingkat keketingan tinggi ditanam tanaman Semangka, Mentimun dan jagung.
\end{abstract}

Kata Kunci: Tingkat Kekeringan, Dan Mitigasi Kegagalan Panen Takalar.

Indonesia merupakan Negara kepulauan yang beriklim tropis dengan curah hujan sangat tinggi. Pada musim hujan tejadi bencana banjir yang menyebabkan kerugian yaitu kehilangan nyawa dan harta benda, dan pada musim kemarau terjadi kekeringan yang menyebabkan gagal panen. Kondisi tersebut silih berganti dan merupakan bencana rutim yang selalu mengancam kehidupan masyarakat. Kekeringan adalah kesenjangan antara air yang tersedia dan air yang diperlukan. Kekeringan dapat terjadi oleh beberapa faktor di daerah dengan jumlah curah hujan yang banyak. Kekeringan disebabkan oleh faktor curah hujan (sebagai masukan), evapotranspirasi sebagai luaran, dan tanah sebagai faktor yang menentukan. Tanah yang tidak bervegetasi menerima sinar matahari dan angin maka akan terjadi penguapan secara lansung di permukaannya Hal ini dapat menyebabkan kehilangan air yang cukup besar di daerah pertanian baik yang memiliki irigasi maupun tidak (Tyasyono, 2006).

Di Wilayah Indonesia kekeringan dipengaruhi oleh dua monsoon yaitu Asia dan Australia, dan faktor lokal, sehingga curah hujan bervarisi antar wilayah. Di Wilayah Provinsi Sulawesi Selatan dari Utara ke Selatan curah 
hujannya semakin berkurang. Di pantai Barat Sulawesi Selatan yang paling kering yaitu Kabupaten Takalar (Nasiah dan Suprapta, 2009).

Kabupaten Takalar terdiri atas 9 kecamatan yaitu : Galesong, Galesong Utara, Galesong Selatan, Mangngara Bombang, Mappkasunggu, Pattallassang, Polombangkeng Uatara, Polongbangkeng Selatan, dan Sanrobone. Daerah penelitian seluruhnya seluas sekitar 57.338,77 Ha. Iklim daerah penelitian antara lain ditentukan oleh faktor curah hujan, unsur-unsur cuaca seperti; suhu udara, angin, kelembaban udara, tekanan udara, radiasi matahari, ketinggian tempat, dan letak lintang. Banyak cara untuk menentukan tipe iklim suatu wilayah. Koppen mendasarkan pada rasio nilai antara jumlah hujan rata-rata tahunan dan jumlah hujan bulan kering serta suhu udara.

Bahan induk jenis tanah di daerah penelitian sebagian besar berasal dari bahan batuan endapan aluviun dan pantai, formasi Camba, Formasi Tonasa, batuan gunung api batu cape Cindako dan lava beku. Jenis tanah Kabupaten Takalar meliputi ; Aluvial, Mediteran dan kompleks Latosol Litosol Coklat Kemerahan. Tipe penggunaan lahan umumnya meliputi ; Sawah, kebun campuran, tegalan, perkebunan, hutan dan permukiman. Perbedaan antara jenis tanah dan jenis tutupan vegetasi tersebut akan menyebabkan perbedaan kapasitas tanah menahan air (Thornthwaite-Mather, 1957).

Jenis tanaman berbeda kebutuhan airnya, maka dalam mengantisipasi kegagalan panen maka tanaman yang dikelola disesuaikan dengan ketersediann air. Faktor Penting yang menentukan tumbuhnya tanaman adalah curah hujan dan suhu (Daldjoeni, 1986). Berdasarkan keragaman kondisi fisik daerah penelitian tersebut, maka timbul pertanyaan bagaimana karakteristik curah hujan, karakteristik evapotranspirasi dan agihan tingkat kekeringan di Kabupaten Takalar.

\section{METODE PENELITIAN}

Penelitian ini dilakukan secara bertahap dan berkesinambungan. Tahap awal, pengumpulan data sekunder yang berupa Peta Topografi lembar Makassar Sheet 46 dan lembar Sentang sheet 47 skala 1 : 125.000 tahun 1946, Peta Penggunaan Lahan skala $1: 100.000$, dan Peta Jenis Tanah skala 1 : 100.000. Peta-peta tersebut digunakan untuk menentukan batas Kabupaten, menentukan lokasi stasiun hujan termasuk letak lintang dan menelaah kembali ketinggiannya yang digunakan untuk analisis.

Sumber data hujan adalah buku laporan pemeriksaan hujan di Sulawesi Selatan terbitan Badan Meteorologi dan Geofisika (BMG) Kota Makassar dengan lama 10 tahun. Hal ini sangat tergantung pada mutu data. Analisis neraca air dengan menggunakan metode Thornthwaite-Mather (1957). Adapun langkah-langkah perhitungan berikut ini.

1. Menentukan ketinggian tempat stasiun penakar curah hujan. Jika pada stasiun tidak memiliki data ketinggian tempat maka ketinggian stasiun diperoleh dengan cara tumpangsusun peta stasiun curah hujan dengan peta Topografi.

2. Menentukan suhu udara bulanan rata-rata. Data suhu udara umumnya sulit diperoleh pada stasiun penakar curah hujan, maka dilakukan interpolasi dari data suhu yang ada. Data suhu udara diambil dari stasiun curah hujan yang ada di Pabrik Gula Takalar dengan ketinggian 20 meter dari permukaan laut. Penyesuaian data suhu udara pada setiap stasiun hujan sebanyak 8 buah stasiun dengan formula Mock (1969) berikut ini.

$$
\begin{aligned}
& \Delta \mathrm{t}=\mathrm{Z} 1-\mathrm{Z} 2 \times 0,006 \\
& \mathrm{t} 2=\mathrm{t} 1 \pm \Delta \mathrm{t} \quad \ldots \ldots \ldots \ldots
\end{aligned}
$$

Keterangan:

$$
\begin{aligned}
& \Delta \mathrm{t}=\text { Beda suhu udara }\left({ }^{\circ} \mathrm{C}\right) \\
& \mathrm{Z} 1=\text { tinggi tempat stasiun } 1 \\
& \mathrm{Z} 2=\text { tinggi tempat stasiun } 2 \\
& \mathrm{t} 1=\text { suhu pada stasiun } 1 \\
& \mathrm{t} 2=\text { suhu pada stasiun } 2
\end{aligned}
$$


3. Menghitung evapotranspirasi dengan metode Thornhwaite-Mather. Penentuan nilai Evapotranspirasi potensial digunakan metode Thornthwaite- Mather (1957) dalam Van Dam (1970) dengan formula :

$$
\begin{aligned}
E p & =f \times E^{*} \ldots \ldots \ldots \ldots \ldots \ldots(2) \\
E p^{*} & =16(10 \mathrm{~T} / \mathrm{I})^{\mathrm{a}} \ldots \ldots \ldots \ldots .(3) \\
I \quad & =\sum \mathrm{i} . \quad \mathrm{i}=1 \mathrm{~s} / \mathrm{d} 12 \text { (Januari }- \text { Desember) }
\end{aligned}
$$

Dalam hal ini :

Ep* = Evapotranspirasi Potensial, dengan perhitungan 1 bulan ; 30 hari

$$
\begin{aligned}
& \mathrm{T}=\text { Suhu udara rata-rata } \\
& \mathrm{I}=\text { Indeks panas tahunan } \\
& \mathrm{i}=\text { Indek panas bulanan } \\
& \mathrm{a} \quad=0.675 \times 10^{-6} \cdot \mathrm{I}^{3}-0,77 \times 10^{-14} \cdot \mathrm{I}^{2}+
\end{aligned}
$$$$
0,01792: I+0,49239
$$

$\mathrm{EP}=$ Evapotranspirasi potensial ( $\mathrm{mm} / \mathrm{bulan})$

$\mathrm{f} \quad=$ Faktor koreksi tergantung letak lintang

4. Menghitung luas poligon. Sebelum menghitung luas poligon terlebih dahulu membuat peta poligon. Cara membuat poligon adalah ;

a. Tarik garis dari masing-masing stasiun dengan garis putus-putus (baik stasiun lokasi penelitian maupun stasiun pembantu sehingga membentuk segitiga dan diusahakan jangan segitiga tumpul.

b. Tarik garis tegak lurus terhadap sisi segitiga.

c. Hasil dari penarikan garis tersebut diperoleh poligon dari setiap stasiun penakar curah hujan. Untuk menghitung luas polygon digunakan metode bujur sangkar (squart methode) (Sukwardjono dan Massukoco, 1997).

5. Menghitung rata-rata curah hujan. Data curah hujan yang digunakan adalah data curah hujan 10 tahun terakhir di wilayah Kabupaten
Takalar. Rata-rata curah hujan dihitung dengan formula berikut ini.

$$
\mathrm{P}=\frac{P 1 . A 1}{A 1}
$$

Dalam hal ini :

$\mathrm{P}=$ Rata-rata curah hujan

P1 = Jumlah curah hujan pada stasiun 1

A1 $=$ Luas poligon stasiun 1

6. Menghitung Water Holding Capacity (WHC). Data yang digunakan dalam menghitung water holding capacity adalah data jenis penggunaan lahan dan data tekstur tanah (Thornthwaite, 1957). Untuk menghitung besar water holding capacity adalah pada suatu lahan maka dilakukan langkah-langkah sebagai berikut.

a. Menumpangsusun (overlay) peta jenis tanah dan peta Penggunaan lahan. Hasil tumpangsusun tersebut dijadikan dasar untuk mengambil sampel tanah kemudian ditentukan tekstur tanah dari masing-masing jenis penggunaan lahan.

b. Peta hasil tumpangsusun (a) kemudian ditumpangsusun lagi dengan peta polygon Thiessen. Untuk mengetahui air yang tersedia pada masing-masing polygon maka disesuaikan dengan table Water Holding Capacity (WHC).

7. Menghitung Accumulation Potensial Water Loss (APWL). Menghitung APWL dilakukan dengan cara menjumlahkan angka pada bulan yang negatif.

8. Perhitungan Storage or Moisture Content in the rooted zone $(\mathrm{St})$. Untuk menghitung $\mathrm{St}$, formula yang digunakan adalah :

$$
\mathrm{St}=\text { Sto. } \mathrm{e}^{-\mathrm{APWL} / \mathrm{Sto} \ldots \ldots \ldots \ldots \ldots \ldots \ldots \ldots \ldots . .(5)}
$$

Dalam hal ini :

Sto $=$ Storage in the field capacity

e $=$ Bilangan nafier 
9. Perhitungan Penambahan Air (St), yaitu dengan cara mengurangi nilai (St) pada bulan yang bersangkutan dengan bulan sebelumnya (Thornthwaite, 1957).

10. Perhitungan Evapotranspirasi Aktual (EA). Pada bulan basah $(\mathrm{P}>\mathrm{PE})$ maka $\mathrm{EA}=\mathrm{PE}$ Pada bulan kering $(\mathrm{P}<\mathrm{PE})$ maka, $\mathrm{AE}=\mathrm{P}+\Delta \mathrm{St}$ (Thornthwaite dalam Darmakusuma, 1990).

11. Defisit (D) diperoleh dengan mencari selisih antara Evapotranspirasi potensial (EP) dengan evapotranspirasi Aktual (EA), dengan formula berikut ini.

$$
\mathrm{D}=\mathrm{PE}-\mathrm{EA}
$$

(Thorntwaite dalam Darmakusuma, 1990)

12. Menghitung Indeks Kekeringan. Penentuan nilai indeks kekeringan digunakan formula Thornthwaite (1957) berikut ini.

$$
\mathrm{Ia}=\mathrm{d} / \mathrm{n} .100
$$

Dalam hal ini :

$$
\begin{aligned}
& \text { Ia }=\text { Indeks kekeringan } \\
& \mathrm{d}=\text { Defisit } \\
& \mathrm{n}=\text { Kebutuhan air (EP) }
\end{aligned}
$$

13. Menentukan tingkat kekeringan. Untuk menentukan tingkat kekeringan digunakan kriteria ILACO B.V (1981), lihat Tabel 1.

14. Peta tingkat kekeringan. Penggambaran peta tingkat kekeringan (ia) dilakukan dengan mengeplot nilai Ia pada setiap stasiun curah hujan, kemudian membuat garis batas wilayah dengan cara interpolasi linier yang didasarkan juga pada batas poligon.

\section{HASIL DAN PEMBAHASAN Karakteristik Curah Hujan}

Curah hujan merupakan salah satu unsur cuaca dan iklim yang sangat berpengaruh terhadap kondisi cuaca dan ilkim di suatu daerah. Hujan (rain) menurut Marbun (1979) adalah air yang jatuh dari awan akibat adanya pembekuan kondensasi dimana telah melampaui titik beku. Curah hujan dibatasi sebagai tinggi air hujan dalam mm yang diterima di permukaan bumi sebelum mengalami aliran permukaan, evaporasi, dan peresapan/perembesan ke dalam tanah.

Besar curah hujan rata-rata bulanan dari 6 stasiun penakar hujan yang tersebar tidak merata di wilayah Kabupaten Takalar. Data curah hujan yang digunakan adalah selama 10 tahun yakni dari tahun 2006 - 2015. Curah hujan rerata bulanan Kabupaten Takalar terbesar pada bulan Januari yaitu sebesar 835,5 mm pada stasiun Bonto Mangape dan terkecil pada bulan Agustus yaitu sebesar 9,5 mm di Palomo Selatan Untuk rerata curah hujan tahunan tertinggi di Stasiun Bonto Mangape sebesar 3546,69 $\mathrm{mm} /$ tahun, dan terendah di Stasiun Lengkese sebesar 2282,8 mm/tahun. Variasi curah hujan dari utara ke Selatan semakin rendah, sesuai hasil penelitian tahun 2009, di pantai barat dari utara ke selatan curah hujannya semakin rendah (Nasiah dan Suprapta, 2009).

Faktor yang mempengaruhi curah hujan adalah monsum (angin musim). Monsum Asia dan Monsum Australia menunjukkan karakter yang berbeda. Monsum Asia lebih lembab ketimbang munsom Australia. Monsum Asia disebut Monsum Barat yaitu pada bulan Desember, Januari, Februari. Kondisi tersebut menyebabkan terjadi musim hujan di Indonesia yaitu pada bulan Oktober hingga April. Monsum Timur yaitu pada bulan Juni, juli, dan Agustus, menyebabkan kemarau di Indonesia pada bulan April sampai Oktober (Tjahyono, 2006).

\section{Suhu Udara}

Suhu udara merupakan salah satu unsur cuaca dan iklim yang sangat berpengaruh terhadap kondisi cuaca dan iklim suatu wilayah. Data suhu udara dalam penelitian ini dasarnya diambil dari pabrik gula Takalar yang berada pada ketinggian 20 meter dpal. Data suhu udara tersebut dijadikan acuan untuk menginterpolasi suhu udara pada stasiun lain yang ada di wilayah Kabupaten Takalar. Rata-rata suhu udara bulanan di Kabupaten Takalar berkisar antara $25,41^{\circ} \mathrm{C}$ hingga $28,14{ }^{\circ} \mathrm{C}$. Rerata Suhu tertinggi pada bulan Oktober di stasiun Patalassang dan rerata suhu terendah pada stasiun 
Malewang pada bulan April. Hal tersebut menunjukkan bahwa suhu udara dari tempat rendah ke tempat tinggi semakin menurun. Di wilayah kabupaten Takalar variasi suhu udara rendah karena topografinya juga hanya berkisar 0 hingga. $600 \mathrm{~m}$ dpal. Suhu diperngaruhi oleh Topografi dan lintang. Setiap kenaikan $100 \mathrm{~m}$ maka suhu turun $0,6^{\circ} \mathrm{C}$. (Mock, 1957).

\section{Evapotranspirasi}

Faktor penting dalam menentukan besar kecilnya Evapotranspirasi adalah suhu udara, letak lintang, dan lengas tanah. Evapotranspirasi yang digunakan dalam penelitian ini adalah evapotranspirasi potensial dan evapotranspirasi aktual. Evapotranspirasi potensial ditentukan oleh dua unsur yaitu; suhu udara dan letak lintang (faktor koreksi). Evapotranspirasi aktual selain dipengaruhi oleh kedua faktor tersebut di atas juga dipengaruhi oleh faktor kelengasan tanah.

Rata-rata evapotranspirasi potensial bulanan di wilayah Kabupaten Takalar berkisar antara 112,9 $\mathrm{mm}$ hingga 170,8 $\mathrm{mm}$. Evapotranspirasi potensial yang terendah di stasiun Patalassang pada bulan Juli dan tertinggi pada bulan Desember juga di stasiun Patalassang. Evapotranspirasi potensial rerata tahunan di Kabupaten Takalar sebesar 1428,76 mm di Palomo Selatan hingga 1576,28 mm di Patalassang. Stasiun yang evapotranspirasi bulanannya lebih dari 100 mm yaitu hampir semua stasiun di Kabupaten Takalar.

Evapotranspirasi aktual tidak jauh berbeda dengan nilai evapotranspirasi potensial. Beberapa bulan yang mempunyai nilai yang hampir sama, bahkan ada yang sama. Evapotranspirasi aktual yang sama dengan evapotranspirasi potensial adalah bulan dimana curah hujannya lebih besar dari pada evapotranspirasi potensial. Yang jumlah bulan terbanyak yang sama antara evapotranspirasi potennsial dengan aktual yaitu 9 bulan di stasiun Malewang Kecamatan Polombangkeng Utara. Dari Malewang ke Utara Bontomangape dan Bajeng semakin berkurang jumlah Ep sama dengan EA menjadi 6 bulan di Kecamatan Galesong Utara. Begitu juga dari Malewang ke Timur dan selatan semakin berkurang jumlah bulan yang EP sama dengan EA. Hal ini sesuai dengan jumlah curah hujan, semakin tinggi curah hujannya maka semakin memberi peluang Ep sama dengan EA.

\section{Tingkat Kekeringan}

Kekeringan (drught) adalah berkurangnya curah hujan yang cukup besar dan berlangsung lama dan dapat mempengaruhi kehidupan tanaman, hewan pada suatu daerah, serta akan menyebabkan berkurangnya keperluan hidup sehari-hari maupun untuk kebutuhan tanaman, terutama terjadi di daerah yang biasanya cukup untuk tujuan semacam itu (Cow, 1994; dalam Rosmini, 2001).

Kekeringan dapat terjadi apabila evapotranspirasi potensial bulanan maupun tahunan lebih tinggi dibanding presipitasi. Indeks kekeringan dipengaruhi oleh beberapa faktor yaitu ; curah hujan, evapotranspirasi potensial, kemampuan tanah menyimpang air, dan evapotranspirasi aktual.

Indeks kekeringan bulanan di wilayah Kabupaten Takalar berkisar antara 0 hingga 115,78 persen. Indeks kekeringan bulanan tertinggi di stasiun Polomo Selatan pada bulan Agustus. Tinggi rendahnya nilai indeks kekeringan dapat dilihat Gambar 2. Indeks kekeringan tahunan di wilayah Kabupaten Takalar berkisar antara 9,2 hingga 37,26 persen. Nilai indeks kekerinmgan tertinggi di stasiun Polomo Selatan yaitu 37,26 persen, dan terendah di stasiun Malewang dengan nilai 9,2 persen. 


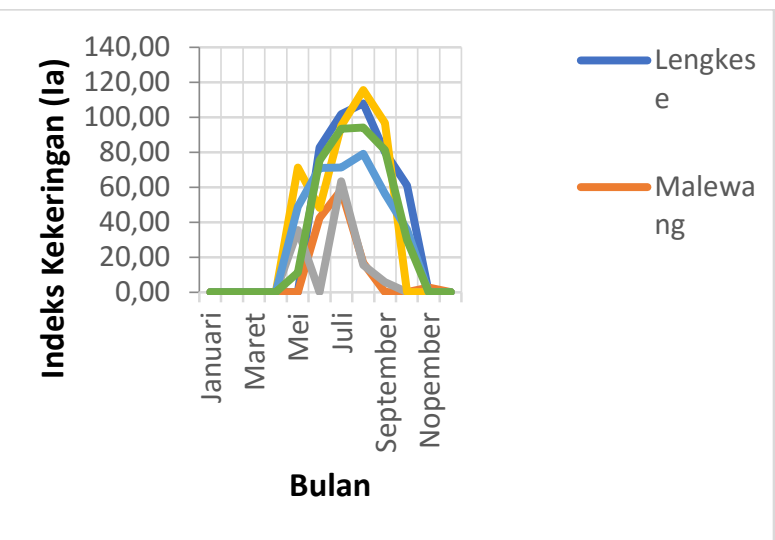

Gambar 1. Grafik Indeks Kekeringan Bulanan di Kabupaten Takalar

Jika nilai indeks kekeringan tersebut diklasifikasikan berdasarkan kriteria indeks kekeringan yang ditetapkan ILACO (1981), yang terdiri atas tiga kategori yaitu ; <16,7 (rendah), 16,7 - 33,3 (sedang), dan > 33,3 (tinggi). Tingkat kekeringan bulanan yang masuk kategori tinggi pada bulan Mei hingga Oktober, sebarannya lihat Gambar 3. Gambar 3 menunjukkan tidak ada kekurangan air yaitu dari bulan November hingga April merata di seluruh wilayah kabupaten Takalar. Akan tetapi sebaliknya bulan Mei hingga Oktober tingkat kekeringan bulanan tinggi. Tingkat kekeringan tinggi tersebar merata di seluruh wilayah kabupaten Takalar yaitu pada bulan Juli. Wilayah yang paling lama mengalami kekeringan tinggi yaitu Patalassang Kec. Mangngarabombang selama 6 bulan dari bulan Mei hingga Oktober. Hal itu disebabkan curah hujannya rendah. Curah hujan rendah disebabkan karena morfologi wilayahnya hampir datar.

Tingkat kekeringan tahunan yang masuk kategori tinggi yaitu 2 stasiun; Palomo Selatan dan Lengkese. Kategori rendah ada 2 stasiun yaitu'; Malewang dan Bontomangape, Agihan tingkat kekeringan tinggi tersebar di wilayah bagian timur dan selatan Kabupaten Takalar meliputi wilayah ; Palomo Selatan dan Lengkese. Akan tetapi wilayah tingkat kekeringannya rendah di wilayah bagian tengah Kabupaten Takalar yaitu Malewang dan Bontomangape. Dari barat ke timur tingkat kekeringannya semakin tinggi. Kondisi tingkat kekeringan di Kabupaten Takalar sangat dipengaruhi oleh curah hujan. Hal itu sesuai yang dikemukakan Bayong bahwa Indeks kekeringan di Benua Maritim praktis lebih dipengaruhi oleh unsur curah hujan dari pada temperatur sesuai yang dikemukakan Bayong (Tjahyono, 2006).

\section{Upaya Mitigasi Kegagalan Panen}

Upaya mitigasi kegagalan panen yaitu menyesuaikan jenis tanaman dengan tingkat kekeringan. Tingkat kekeringan tinggi, curah hujannya sangat rendah. Di wilayah kabupaten Takalar tingkat kekeringan tinggi pada bulan Mei hingga Oktober, maka pengelolaan lahan pertanian disesuaikan dengan Jenis tanaman yang tidak membutuhkan air yang banyak yaitu; semangka, mentimun, jagung, dan lombok. Faktor penting menentukan tumbuhnya tanaman adalah ketersedian air (curah hujan) dan suhu (Daljoeni, 1986).

\section{KESIMPULAN}

Kesimpulan yang dapat ditarik dari hasil penelitian ini yaitu karakterisitk curah hujan bulanan di wilayah Kabupaten Takalar berkisar antara 9,5 mm hingga $835,5 \mathrm{~mm}$. Curah hujan bulanan terbesar di stasiun Bonto Mangape dan terkecil di stasiun Palomo Selatan. Curah hujan tahunan berkisar antara 2282,8 $\mathrm{mm}$ hingga 3546,69 $\mathrm{mm} /$ tahun. Karakteristik Evapotranspirasi potensial bulanan di wilayah kabupaten Takalar berkisar antara $56 \mathrm{~mm}$ hingga $175 \mathrm{~mm}$. Evapotranspirasi potensial rerata tahunan di Kabupaten Takalar tertinggi di stasiun Palomo Selatan sebesar 1778 $\mathrm{mm}$ dan terendah di stasiun Bonto Mangape sebesar $781 \mathrm{~mm}$. Selain itu agihan tingkat kekeringan tinggi tersebar di wilayah Selatan dan timur meliputi wilayah ; Palomo Selatan dan Lengkese, dan tingkat kekeringannya rendah di wilayah Malewang dan Bonto Mangape. 


\section{DAFTAR PUSTAKA}

Asdak, Chay. 1995. Hidrologi dan Pengelolaan Daerah Aliran Sungai. Gadjah Mada University Press. Yogyakarta.

Darmakusuma, Darmanto. 1977. Pengeloloaan Sumberdaya Air. (Catatan Kuliah). Fakultas Geografi UGM. Yogyakarta.

Daldjoni. 1986. Pokok Pokok Klimatologi. Alumni. Bandung.

ILACO, B.V., 1981. Agriculture Compendium for

Rural Development in the Tropic and Subtropics. Elsevier, Amterdam.

Kartasapoetra, Ance Gunarsih. Klimatologi : Pengaruh Iklim Terhadap Tanah dan Tanaman. 2008 : Bumi Aksara : Jakarta.

Maru, Rosmini. 2001. Evaluasi Tingkat Kekeringan Daerah Ledakan Hama Belalang Kembara di Pulau Sumba. Thesis. Fakultas Geografi UGM. Yogyakarta.

Maryono, Agus. 2005. Menangani Banjir, Kekeringan dan Lingkungan. Gadjah Mada University Press. Yogyakarta.

Mock, 1969. Land Capability Appraisal in Indonesia. Soil Research Institut, Bogor.

Mujtahiddin, Muhammad Iid. 2014. Analisis Spasial Indeks Kekeringan Kabupaten Indramayu. Jurnal Meteorologi dan Geofisika Vol. 15 No. 2 Tahun 2014. Bandung.

Munir, Muchammad Misbachul, Bandi Sasmito, dan Haniah. 2015. Analisis Pola Kekeringan Lahan Pertanian di Kabupaten
Kendal Dengan Menggunakan Algoritma Thermal Vegetation Index Dari Citra Satelit Modis Terra. Jurnal Geodesi Undip. Volume 4, No. 4 Tahun 201. ISSN: 2337845X.Semarang.

Nurrahman, Fery Irfan dan Adjie Pamungkas. Identifikasi Sebaran Daerah Rawan Bahaya Kekeringan Meteotologi di Kabupaten Lamongan. Jurnal Teknik Pomois Vol. 2 No. 2 2013. ISSN: 2337-3539. Surabaya.

Dewi Galuh Condro Kirono, 1999. Analisis Curah Hujan Untuk Antisipasi Kekeringan dan Mitigasinya di Daerah Aliran Sungai Progo. Majalah Geografi Indonesia. Tahun 13 nomor 23. Fakultas Geografi Universitas Gadjah Mada. Yogyakarta.

Sutikno, dkk,. 1995. Pemetaan Daerah Rawan Bencana Alam Provinsi Jawa Tengah. Laporan Penelitian. Kerjasama antara BAPPEDA TK I. Provinsi Jawa Tengah dengan Fakultas Geografi UGM. Yogyakarta.

Thornthwaite and Mather, 1957. Tables and Instructions for Computing Evapotranspiration and The Water Balance. Drexel Climatologi Laboratory, New Yersei.

Tika, Mohammad Pabundu. Metode Penelitian Geografi. 2005. Bumi Aksara: Jakarta.

Tjahyono, Bayong. 2006. Ilmu Kebumian dan Antariksa. PT. Remaja Rosdakarya. Bandung. 